\title{
Emission from a dual fuel operated diesel engine fuelled with Calophyllum Inophyllum biodiesel and producer gas
}

\author{
S.K. Nayak* and P.C. Mishra \\ School of Mechanical Engineering, KIIT University \\ Bhubaneswar-751024, Odisha, India \\ "E-mail: rohanrocks319@gmail.com, \\ Mobile: +91-8763709850
}

\begin{abstract}
In recent times, the rapid depletion of diesel fuel has resulted in its rising price and hazardous emission from the vehicles. Hence, an alternative fuel is immediately required for substituting diesel in order to improve the country's economic status and security. Therefore, this paper investigates the performance and emission characteristics of a diesel engine operated in dual fuel mode fuelled with calophyllum inophyllum oil methyl ester blends and rice husk generated producer gas. The engine test analysis was carried out at varying load conditions $(0,2,4,6,8,10 \mathrm{~kW})$ keeping the producer gas flow rate constant i.e. at $21.69 \mathrm{~kg} / \mathrm{h}$. The experimental results depict that maximum diesel savings occurred for diesel with producer gas up to $82 \%$, when correlated with the B20 biodiesel blend showing diesel savings of up to $80.6 \%$ at $8 \mathrm{~kW}$ of the optimum loading condition. Now, taking into account the emission parameter i.e. $\mathrm{CO}, \mathrm{CO}_{2}$ and $\mathrm{HC}$ showed an increasing trend while, NOx and the smoke opacity reduced drastically for the dual operated mode. Hence, it might be concluded that the calophyllum inophyllum oil methyl ester with producer gas at a constant gas flow rate up to a $20 \%$ blend i.e. B20 can be utilised as potential fuel for current diesel engines without many engine modifications and problems.
\end{abstract}

Keywords: calophyllum inophyllum; rice husk; diesel engine; transesterification; gasification; emission.

\section{INTRODUCTION}

In this modern era, conventional fuel plays a very important role in the field of industrial developments, transportation, agribusiness and so on, due to its accessibility, ignition properties and higher heating values. In this case, due to the high brake thermal efficiency of diesel engines, it is a more popular vehicle in the transportation and agricultural sectors $[1,2]$. However, there is a rapid depletion in the petroleum reserves because of the enormous fuel consumption as per demand. The International Energy Agency, estimated that by the end of 2030, the net energy consumption will increase by more than 55\% [35]. The Energy Information Administration (EIA) of the United States predicted that net petroleum products utilisation and consumption will increase from around 86 million barrels per day to 110 million barrels per day by the end of $2035[6,7]$. Due to the rapid depletion in conventional fuels, the rising price of petroleum products and major current environmental issues have gathered momentum in finding out a substitute, an alternative source of energy, which can replace the current conventional fuel in the future. Hence, it has become a worldwide challenge to develop a clean, renewable, environmental friendly, easily available and technically feasible advanced fuel. Biodiesel is categorised as 
alternative fuel or advanced fuel, which has the capability to meet the current energy demands all around the globe, thereby reducing global warming [3, 8-11]. According to the literature, renewable energy will become the second largest source of power generation by the end of 2020, and by 2035 it will approach coal as the main source of electricity $[12,13]$. In developing countries such as India and in many other developing countries, biodiesel will play a major role in diminishing the dependence on fossil fuel, the rising price of the products and various effects of global warming, which imparts an adverse effect upon human health [14-17]. Biodiesel is directly produced form straight vegetable oils (SVO'S) such as karanja, mahua, neem, polanga, callophyluminophyllum, jojoba, simarouba etc., which are often referred to as non-edible oils or animal fats, tallow and waste cooking oil by the esterification and transesterification process. The transesterification process is the reaction of a triglyceride (oil) with an alcohol i.e. methanol or ethanol to form methyl or ethyl esters and glycerol as byproducts $[9,18]$. Biodiesel is considered to be safer than diesel because of its higher flash point and fire point. It constitutes a good percentage of oxygen which on burning emits less carbon monoxide $(\mathrm{CO})$ and hydrocarbon $(\mathrm{HC})$, but at the same time it enhances the nitrogen oxide $\left(\mathrm{NO}_{\mathrm{x}}\right)$ emission, which is the most harmful parameter that may lead to acid rain and smog thereby causing environmental degradation.

According to [19-22]., the diesel engine operated in a dual fuel mode gives improved emissions in comparison to that of a normal running mode with enhanced brake thermal efficiency. A diesel engine can be modified to operate in the dual fuel mode, by inducting producer gas i.e. gaseous fuel as primary fuel followed by ignition with biodiesel or diesel as pilot fuel. The producer gas can be generated from various biomass feedstock samples by converting them into gaseous fuel with the help of a gasifier [23]. Producer gas cannot be used in diesel engines with a lower quantity of fuel due to its high octane number $[24,25]$. Hence, the engine needs to be dual fuelled. From various literatures, it is visible that 76-93\% diesel savings occur in the case of running the engine in a dual fuel mode using various alternative fuels $[10,23]$. The main objective of this investigation is to reduce the oxide of nitrogen (NO) and smoke emissions. In case of diesel engines, it is difficult to reduce both NO and smoke emissions because of the trade off curve between them [9]. The composition of producer gas generated from rice husk utilising the down draft gasifier is elaborated in Table 2. This paper mainly emphasises the production of producer gas from rice husk, biodiesel from calophylluminophyllum for determining the emission characteristics of a diesel engine operated in dual fuel mode with an optimum producer gas flow rate of $21.69 \mathrm{~kg} / \mathrm{h}$ under different loading conditions, with the aim of substituting the present conventional fuel.

\section{MATERIALS AND METHODS}

\section{Source of Calophyllum Inophyllum oil}

Calophyllum inophyllum is a medium sized tree up to 7-20 $\mathrm{m}$ in height. It is essentially a littoral tree of the tropical regions. On the west coast, it is found from Mumbai southwards to Southern Kerala and along the east coast, from Odisha southwards. Calophyllum inophyllum can grow in a wide variety of soils ranging from muddy clay to coastal sands, and can also grow in hilly areas as well as in non-cultivable lands, with an annual rainfall ranging from $700-5000 \mathrm{~mm}$. The oil content of the seed ranges from 60-70\% [26]. The high oil content, easy availability, growth on barren lands and low water requirement are the properties which make this oil best suited for the investigation on the diesel engine 
without any modifications. The free fatty acid composition of calophylluminophyllum oil is described in Table 1.

Table 1. Free fatty acid composition of calophyllum inophyllum oil.

\begin{tabular}{llcc}
\hline S1. No & Free fatty acid & Structure & $\begin{array}{c}\text { Calophyllum } \\
\text { inophyllum oil }\end{array}$ \\
\hline 1 & Lauric & C12:0 & 0.75 \\
2 & Myristic & C14:0 & 0.7 \\
3 & Palmitic & C16:0 & 14.3 \\
4 & Palmitoleic & C16:1 & 0.251 \\
5 & Heptadecanoic & C17:0 & 0.1 \\
6 & Heptadecenoic & C17:1 & 0.039 \\
7 & Stearic & C18:0 & 15.38 \\
8 & Oleic & C18:1 & 37.92 \\
9 & Linoleic & C18:2 & 28.33 \\
10 & Linolenic & C18:3 & 0.17 \\
\hline
\end{tabular}

\section{Source of Rice Husk}

Paddy cultivation is carried out in almost all states of India, especially in Andhra Pradesh, Odisha, Bihar, West Bengal, Punjab. The net amount of paddy produced from the aforementioned states is nearly about $50-60 \%$ of the total production from the whole country. The availability of rice husk mainly depends on the production of paddy, paddy processing and husk to paddy ratio (HPR), which varies from 0.1 to 0.3 [27]. The typical composition of rice husk generated producer gas obtained from the gasification process is measured utilising gas chromatography and the collected values are being formulated in Table 2.

Table 2. Compositional analysis of the rice husk producer gas.

\begin{tabular}{llll}
\hline Sl. No & Compositional analysis & Unit & $\begin{array}{l}\text { Rice husk } \\
\text { producer gas }\end{array}$ \\
\hline 1 & Lignin & $\%$ & 25 \\
2 & Hemi-Cellulose & $\%$ & 35 \\
3 & Cellulose & $\%$ & 40 \\
4 & Fixed carbon & $\% \mathrm{db}$ & 13.10 \\
5 & Carbon & $\%$ & 50.3 \\
6 & Hydrogen & $\%$ & 5.3 \\
7 & Nitrogen & $\%$ & 0 \\
8 & Oxygen & $\%$ & 43.4 \\
9 & Sulphur & $\%$ & 0.01 \\
10 & Ash & $\%$ & 1.84 \\
11 & Methane & $\%$ & 2 \\
\hline
\end{tabular}

\section{Preparation of Calophyllum Oil Methyl Ester Blends}

Initially, one litre of neat calophylluminophyllum oil is heated to a temperature of $110^{\circ} \mathrm{C}$ in order to remove the liquid particles present in the oil followed by degumming, utilising $1 \% \mathrm{v} / \mathrm{v}$ (Phosphoric acid) $\mathrm{H}_{3} \mathrm{PO}_{4}$. Then, the degummed oil is processed under the transesterification process where the oil is mixed with $20 \% \mathrm{v} / \mathrm{v}$ of methanol and $7.2 \mathrm{~g}$ of 
sodium hydroxide pellets inside a self fabricated biodiesel reactor as shown in Figure 1 for 1-2 hours maintaining a constant temperature of $60{ }^{0} \mathrm{C}$ with the help of a heating mantle. The oil is then allowed to settle down inside the reactor for about 8-10 hours in order to obtain methyl ester or biodiesel. The biodiesel obtained is further washed with the help of distilled water using 2-3 drops of orthophosporic acid, nearly about 2-3 times for the removal of acids and then heated to a temperature above $100{ }^{\circ} \mathrm{C}$ in order to separate the moisture content from the biodiesel to make it more pure. Now, the biodiesel is blended with diesel in various volume proportions i.e. B10, B20, B30 and B50 where B10 represents $10 \%$ biodiesel and $90 \%$ diesel.

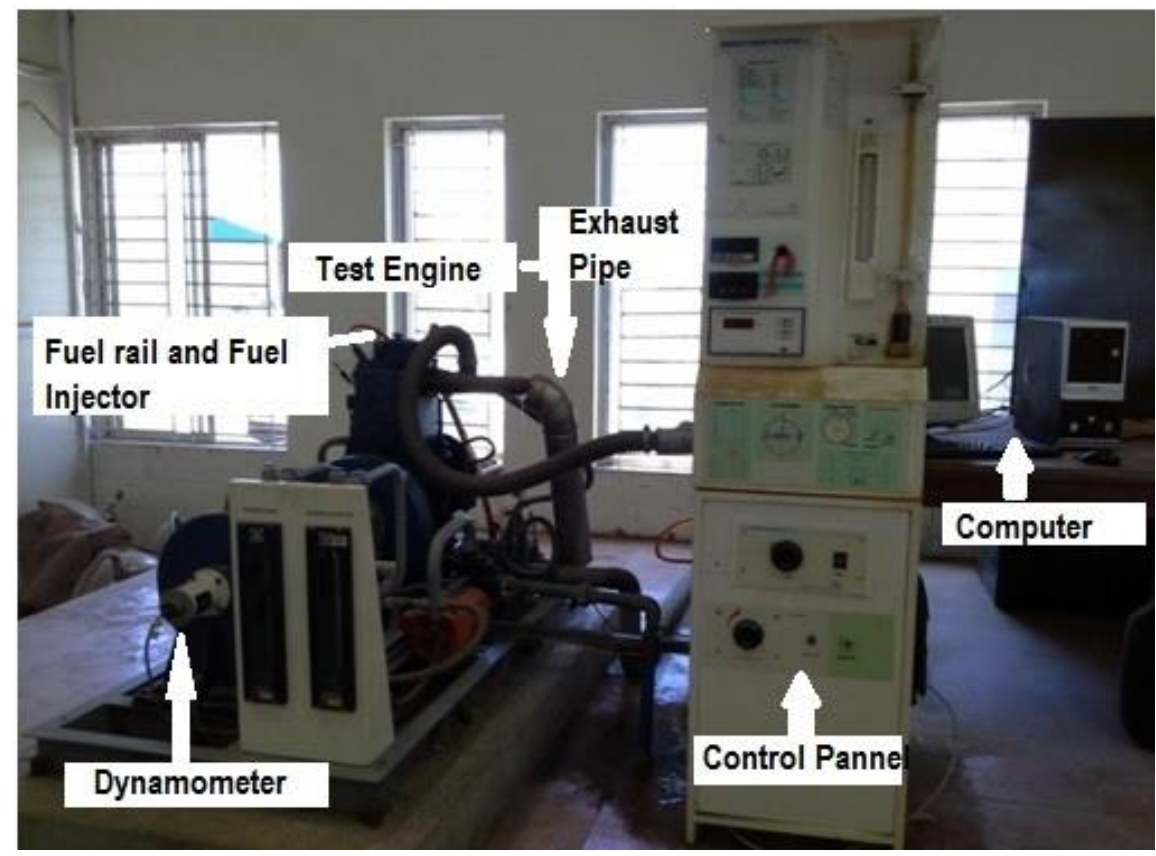

Figure 1. Test engine (Make- K.C.Engineers Pvt. Ltd., Haryana, India).

\section{Physico-Chemical Properties of Biodiesel}

A few biodiesel properties of the calophylluminophyllum oil methyl ester were examined such as the kinematic viscosity, density, flash point, fire point, oxidation stability, calorific value, cetane number, sulphur content, etc. and the results for both the rice husk generated producer gas and calophylluminophyllum oil derived methyl esters are being described in Table 3 and Table 4. The kinematic viscosity is an estimation of an oil's density after a certain period of time. The lesser the density, the easier is its flow. In the case of an engine, an increased viscosity prompts improper working of the fuel injector thereby leading to a poor atomisation of the fuel spay which develops an average mean distance across the fuel beads. ASTM D445 is the favoured system for measuring the kinematic viscosity. The adequate range for the oil's density according to ASTM D6751 is within $1.9-6.0 \mathrm{~mm}^{2} / \mathrm{Sec}$ [9]. Similarly, with respect to transportation and security regulations, a flash point is generally used to represent the ignition properties of a biodiesel. The flash point is the lowest temperature at which the fuel will ignite off when an ignition source is being connected. Biodiesel is considered non-flammable if the flash point is over the limit of $130{ }^{\circ} \mathrm{C}$ as outlined in ASTM D93. The data obtained showed a close resemblance with the data of other researchers as seen from the literatures [28, 29]. 
Table 3. Properties of the rice husk generated producer gas.

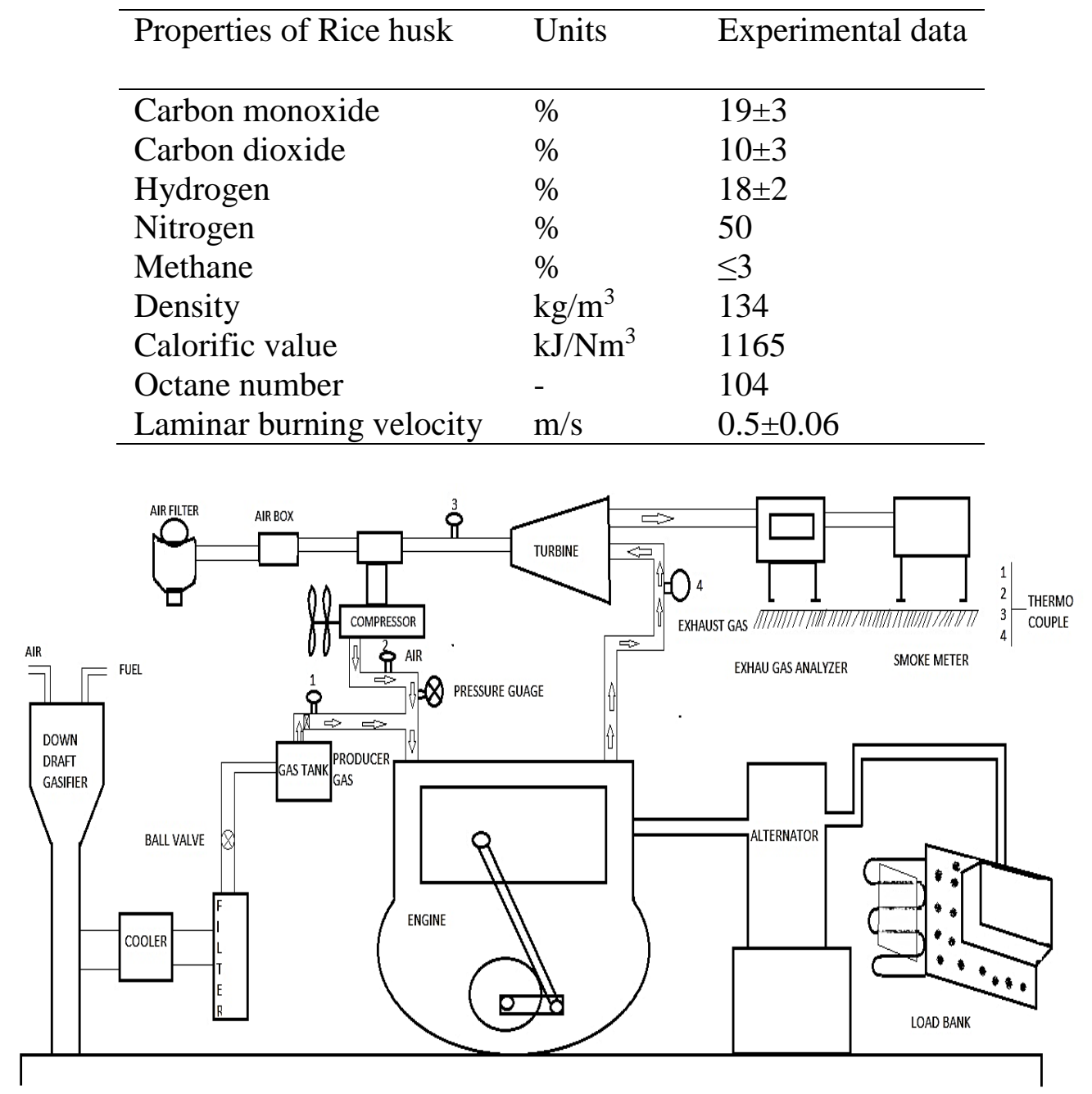

Figure 2. Schematic diagram of the test engine with the down draft gasifier.

\section{Experimentation}

The setup in this experimentation consists of a single cylinder, four stroke, vertical water cooled, diesel engine supplied by K. C. Engineer Pvt. Ltd. Haryana, India, as shown in Figure 1. A downdraft gasifier with a cooling unit, passive filters, fine filters and gas surge tank with a complete setup is shown as a schematic diagram in Figure 2. The complete specification of both engine and gasifier is provided in Table 5 and Table 6 . The rice husk biomass is fed from the top portion of the downdraft gasifier, while the coke is removed from the bottom of the setup manually in a regular interval of time. The producer gas generated in the gasifier enters the engine cylinder at an injection pressure of $220 \mathrm{bar}$, constant speed of $2000 \mathrm{RPM}$ and injection timing of $22^{\circ}$ before the top dead centre (bTDC). The engine test analysis carried out at varying load conditions $(0,2,4,6,8,10 \mathrm{~kW})$ maintains the producer gas flow rate constant i.e. at $21.69 \mathrm{~kg} / \mathrm{h}$. The temperature of the producer gas before entering the cooling system and after exiting it was noted with the help of thermocouples and it was found to be $480{ }^{\circ} \mathrm{C}$ at the inlet and $39{ }^{\circ} \mathrm{C}$ at the outlet of the gasifier cooling system. The emission characteristics were observed under varying load conditions for all test fuels and were measured with the help of a 5-gas analyser (make-AVL, model- Degas 444) and smoke meter (make- AVL, model- C 37). A 
computerised data acquisition system (make- Chino DAS) is used to collect all the data during experimentation by using several detectors.

Table 4. Physico chemical properties of the Calophyllum Inophyllum oil methyl ester.

\begin{tabular}{|c|c|c|c|c|c|c|}
\hline Properties & Units & Diesel & COME & $\begin{array}{l}\text { ASTM } \\
\text { Methods }\end{array}$ & $\begin{array}{l}\text { Reference } \\
(\mathrm{a}, \mathrm{b})\end{array}$ & $\begin{array}{l}\text { Reference } \\
\text { (c) }\end{array}$ \\
\hline Density@40 $9{ }^{0} \mathrm{C}$ & $\mathrm{kg} / \mathrm{m}^{3}$ & 846.3 & 876.8 & D 4052 & 877.6 & 868.6 \\
\hline $\begin{array}{l}\text { Viscosity @ } 40 \\
{ }^{0} \mathrm{C}\end{array}$ & $\mathrm{cSt}$ & 3.64 & 4.72 & D 445 & 5.53 & 4.71 \\
\hline Cetane number & - & 48.3 & 51.9 & D 613 & $\mathrm{~N} / \mathrm{d}$ & $\mathrm{N} / \mathrm{d}$ \\
\hline Iodine number & - & $\mathrm{N} / \mathrm{d}$ & 85 & - & $\mathrm{N} / \mathrm{d}$ & $\mathrm{N} / \mathrm{d}$ \\
\hline Calorific value & $\mathrm{MJ} / \mathrm{kg}$ & 42.72 & 39.88 & D 240 & 39.5 & 39.3 \\
\hline Acid value & $\begin{array}{l}\mathrm{mg} \\
\mathrm{KOH} / \mathrm{g}\end{array}$ & 0.35 & 0.76 & D 664 & $\mathrm{~N} / \mathrm{d}$ & $\mathrm{N} / \mathrm{d}$ \\
\hline Pour point & ${ }^{0} \mathrm{C}$ & -15 & 10 & D 97 & 13 & 8 \\
\hline Cloud point & ${ }^{0} \mathrm{C}$ & 1 & 13 & D 2500 & 12 & 10 \\
\hline Flash point & ${ }^{0} \mathrm{C}$ & 55 & 151 & D 93 & 162.5 & 141.5 \\
\hline $\begin{array}{l}\text { Cold filter } \\
\text { plugging point }\end{array}$ & ${ }^{0} \mathrm{C}$ & -10 & 10 & D 130 & 11 & 8 \\
\hline Carbon & $\mathrm{wt} \%$ & 81.33 & - & - & $\mathrm{N} / \mathrm{d}$ & $\mathrm{N} / \mathrm{d}$ \\
\hline Hydrogen & $\mathrm{wt} \%$ & 12.78 & - & - & $\mathrm{N} / \mathrm{d}$ & $\mathrm{N} / \mathrm{d}$ \\
\hline Ash content & $\% \mathrm{w} / \mathrm{w}$ & $\mathrm{N} / \mathrm{d}$ & 0.026 & D 482 & $\mathrm{~N} / \mathrm{d}$ & $\mathrm{N} / \mathrm{d}$ \\
\hline Sulphur & $\% \mathrm{~m} / \mathrm{m}$ & 0.32 & 1.6 & D 5453 & 4.11 & $\mathrm{~N} / \mathrm{d}$ \\
\hline
\end{tabular}

(a) [28]; (b) [29]; (c) [30]

Table 5. Test engine specification.

\begin{tabular}{ll}
\hline Test Engine & \\
\hline Make & K.C. Engineers Pvt. Ltd. \\
Rated horsepower $(\mathrm{kW})$ & 14 \\
Number of cylinders & 2 \\
Number of strokes & 4 \\
Rotation per minute (RPM) & 1500 \\
Compression ratio (CR) & $16: 1$ \\
Stroke length (mm) & 110 \\
Bore diameter $(\mathrm{mm})$ & 114 \\
\hline
\end{tabular}

Table 6. Down draft gasifier detail specification.

\begin{tabular}{ll}
\hline Downdraft gasifier & \\
\hline Gasifier model & WBG-15 \\
Gasifier type & Downdraft type \\
Gas flow rate & $37.5 \mathrm{Nm}^{3} / \mathrm{hr}$ \\
Average gas calorific value & $1000 \mathrm{~kJ} / \mathrm{Nm}^{3}$ \\
Gasification temperature & $1000-2000{ }^{0} \mathrm{C}$ \\
Fuel storage capacity & $100 \mathrm{~kg}$ (approximately) \\
Permissible moisture & $<22 \%$ on weight basis \\
Biomass consumption & $12-15 \mathrm{~kg} / \mathrm{hr}$ \\
Ash drawer for ash removal & Manual \\
\hline
\end{tabular}




\section{RESULTS AND DISCUSSION}

\section{Brake Thermal Efficiency}

The variation of the brake thermal efficiency with respect to the load is shown in Figure 3. The figure depicts a continuous rise in BTE for all the prepared test fuels with an increase in load of up to $8 \mathrm{~kW}$ for both the operating modes because of a higher intake air temperature at the time of fuel injection in the diesel engines resulting in an improved combustion [31, 32]. The BTE shows a decreasing trend after an $8 \mathrm{~kW}$ load because of partial combustion due to the shortage of the oxygen content. Diesel exhibits the highest BTE followed by biodiesel, due to the fact that biodiesel possesses higher viscosity causing a poor atomisation of the fuel resulting in an incomplete combustion. The BTE is lowest of the engine operated in dual fuel mode because the rice husk producer gas has the lowest certain number in comparison to diesel and biodiesel; furthermore, it has a reduced oxygen content which degrades the combustion efficiency of the engine [31]. Similarly, with an increase in the biodiesel blend percentage, the BTE is less for both single and dual operated modes (values of B10 shows nearby result) than that of the fossil diesel because of the high viscosity and low volatility value of the calophyllum inophyllum vegetable oil in blended form leading to poor atomisation resulting in an inferior combustion.

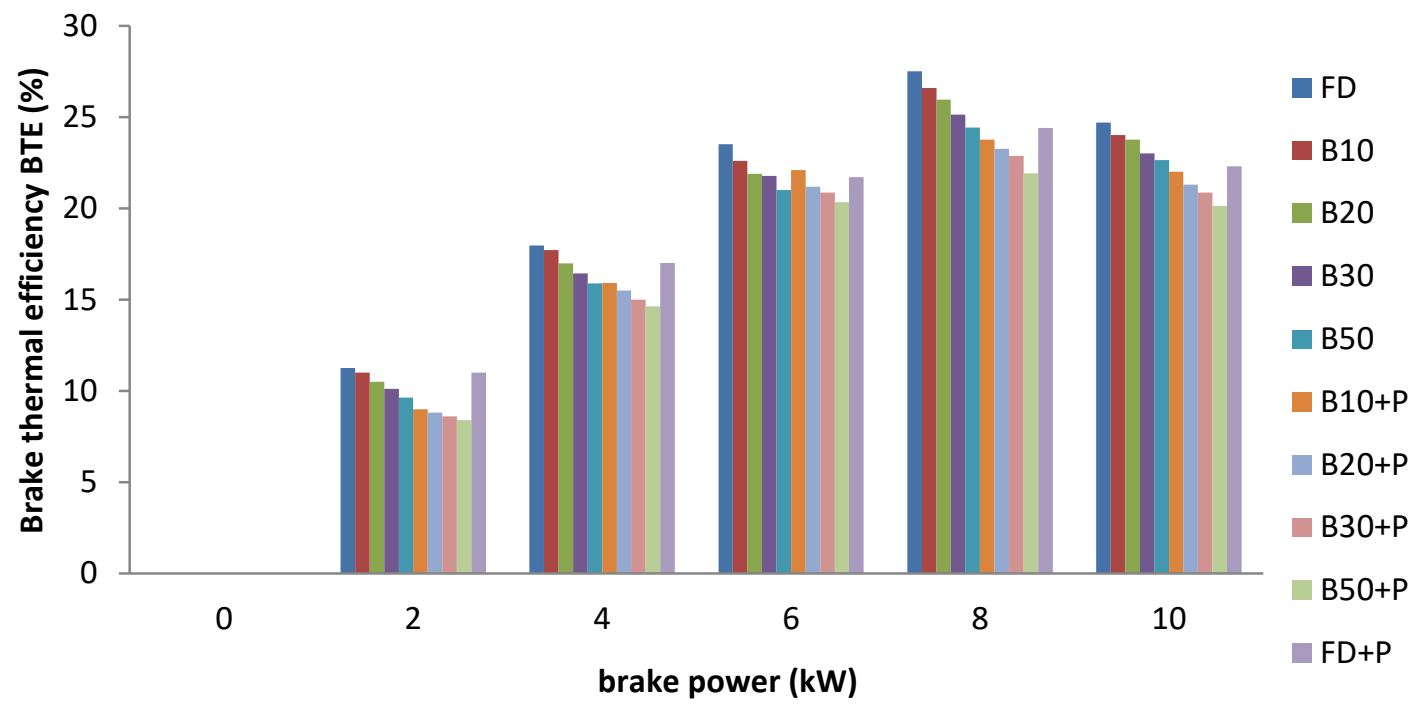

Figure 3. Variation of the brake thermal efficiency with different loads

\section{Brake Specific Energy Consumption}

The variation of the brake specific energy consumption with respect to the load is shown in Figure 4. From the above graph it is seen that the BSEC shows a decreasing curve with respect to the load until up to $8 \mathrm{~kW}$ because of the complete combustion, which is due to a higher intake air temperature during the time of fuel injection into the diesel engines . The BSEC is more for the dual fuel operation in comparison to the other test fuels and single operating mode because of the lower calorific value of the dual fuel. The BSEC shows an increasing trend after $8 \mathrm{~kW}$ for all the prepared test fuels, due to the fact that the oxygen content is generally reduced which leads to a partial combustion inside the engine cylinder [19]. Similarly, with an increase in the biodiesel blend percentage, the BSEC is higher for both the single and dual operated mode (highest for B50+producer gas) than that of the fossil diesel because of the high density and low calorific value of the calophylluminophyllum vegetable oil. 


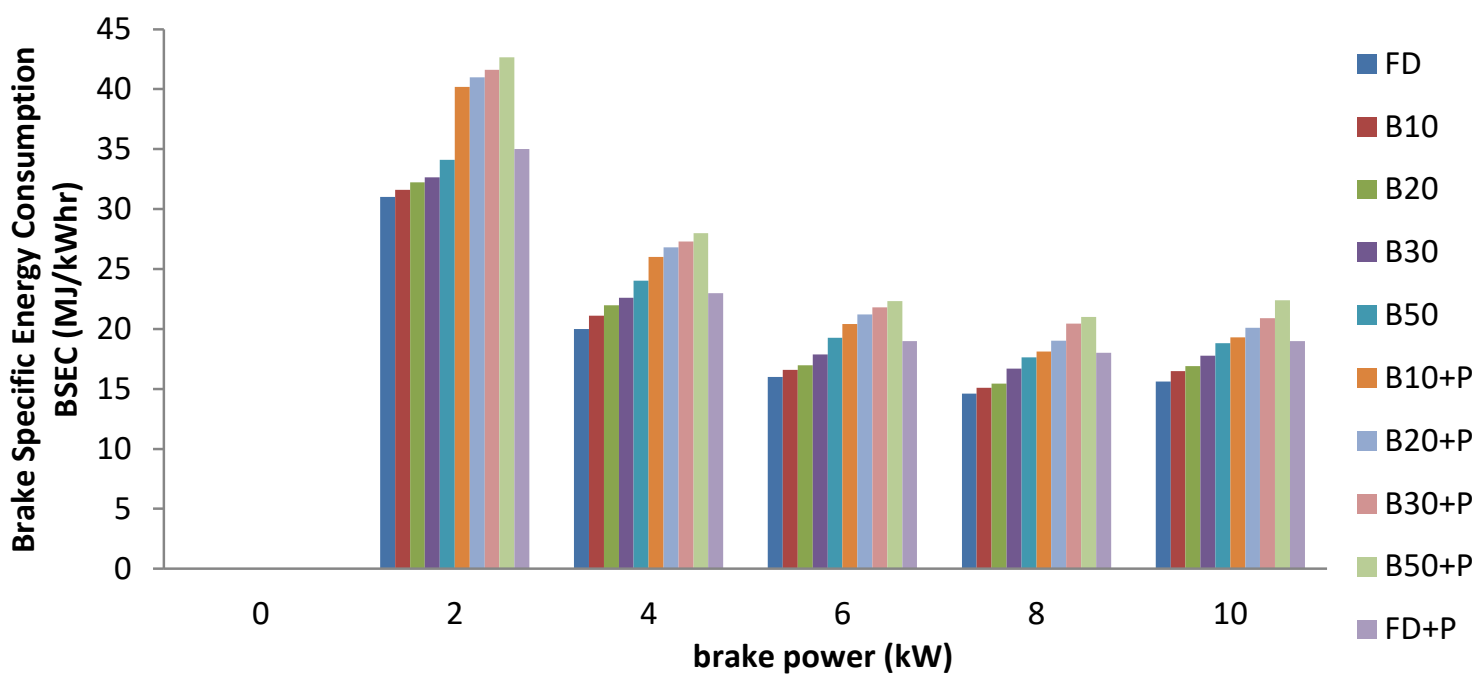

Figure 4. Variation of the brake specific energy consumption with different loads

\section{Exhaust Gas Temperature}

The variation of brake thermal efficiency with respect to the load is shown in Figure 5. From the above curves it is seen that the EGT increases for all the prepared test fuels, but more for the dual fuel mode, which might be due to a higher supply of energy into the engine cylinder, resulting in a high combustion temperature, thereby increasing the EGT $[19,30]$. It is quite clear from the curves that the EGT is higher for the dual operated mode because of a larger delay period of slow combustion producer gas. Similarly, with an increase in the biodiesel blend percentage, the EGT is less for the single fuel mode (lowest for B20) but more than that of fossil diesel because of the high energy which is liberated in the final part of the combustion phase. This might be due to the higher viscosity of the oil and large fuel droplet size, which may affect the combustion duration inside the cylinder in comparison to fossil diesel.

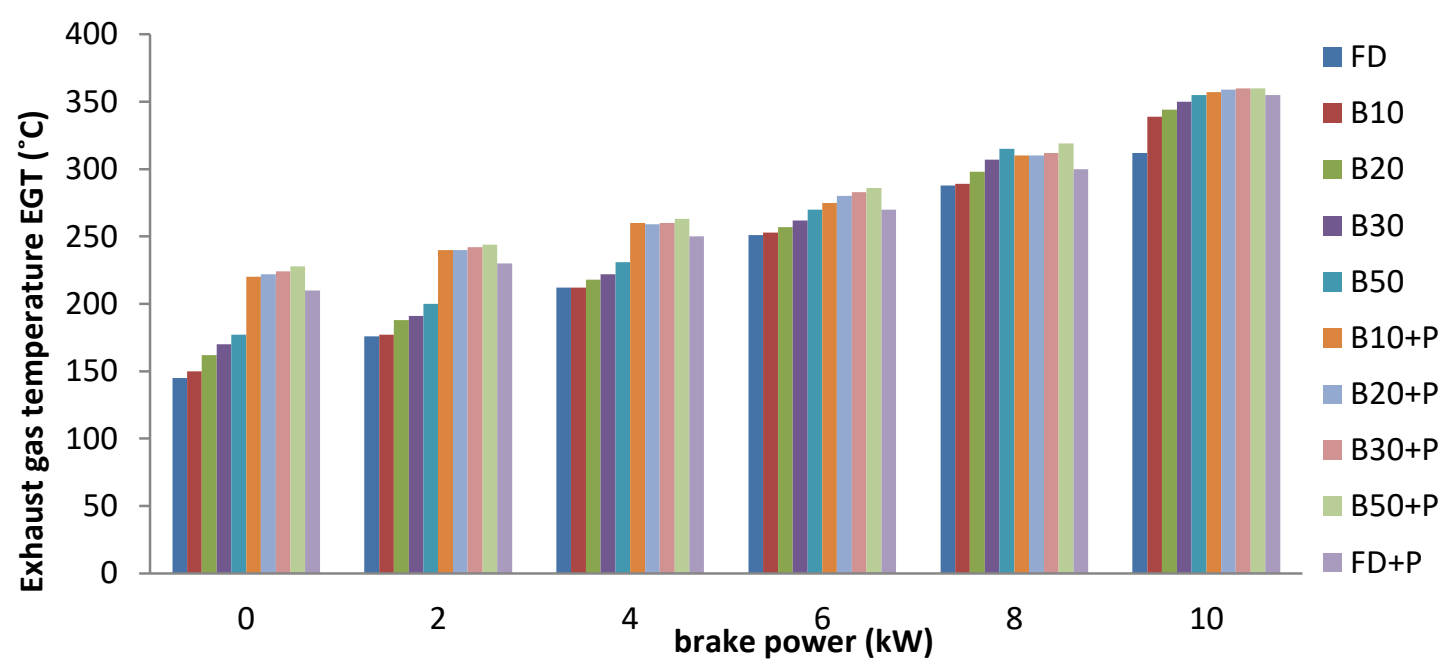

Figure 5. Variation of exhaust gas temperature with different loads.

\section{Carbon Monoxide Emission}

The variation of carbon monoxide with respect to the load is depicted in Figure 6. From the above graph it is quite obvious that the $\mathrm{CO}$ emission is higher for the dual operated 
mode rather than for the fossil diesel fuelling mode. It might be due to the higher ignition delay of the producer gas that may lead to a decrease in the adiabatic combustion temperature thereby resulting in a partial combustion [32]. Secondly, the producer gas contains 20-22\% CO whose combustion may increase the $\mathrm{CO}$ emissions. Figure 6 also depicts that with the increase in load, the $\mathrm{CO}$ emission declines to up to $8 \mathrm{~kW}$ because of the higher intake air temperature which enhances the oxidation reaction. But, at peak load, the $\mathrm{CO}$ increases due to the fact that at peak load the amount of the oxygen content in the air-fuel mixture reduces thus resulting in a partial or incomplete combustion [19] . B20 stands with the lowest $\mathrm{CO}$ emission in the case of both natural and dual fuel operated modes because of the higher oxygen content resulting in a complete oxidation of the calophylluminophyllum biodiesel thereby leading to better spray characteristics $[30,32]$. The $\mathrm{CO}$ emission is found to be lowest for $\mathrm{B} 20+\mathrm{P}(0.29 \%)$ among all test fuel blends in the dual fuel mode, while that of B20 $(0.022 \%)$ in the fossil diesel fuelling mode at optimum loading condition for all test fuel blends.

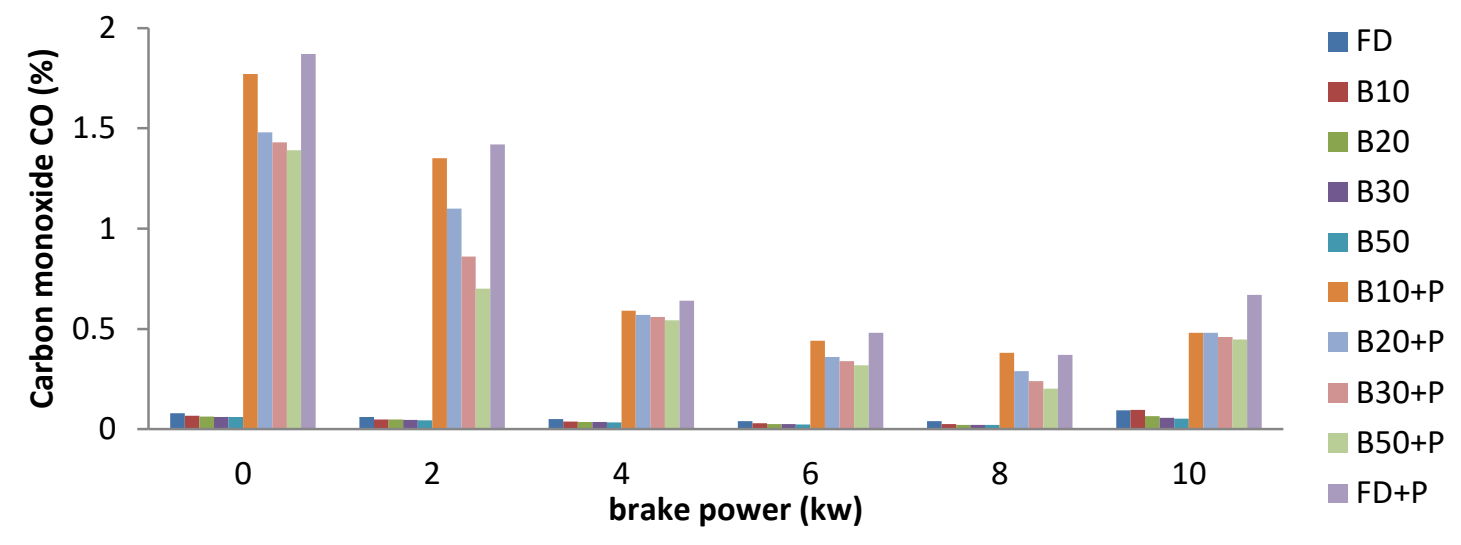

Figure 6. Variation of carbon monoxide with different loads.

\section{Carbon Dioxide Emission}

The variation of carbon dioxide with respect to the load is shown in Figure 7. The CO2 emission is higher for the dual operated mode rather than for the fossil diesel fuelling mode because of the fact that the generated producer gas consists of both $\mathrm{CO}(20-22 \%)$ and $\mathrm{CO}_{2}(13-14 \%)$. Thus, the increase in the combustion temperature gives a steep raise in the $\mathrm{CO}_{2}$ emission. It is also observed that with the increase in the blend percentage of biodiesel, there is a continuous reduction in $\mathrm{CO}_{2}$ in comparison to diesel for both operating modes because biodiesel contains an increased oxygen content, which leads to a complete combustion resulting in a reduced $\mathrm{CO}_{2}$ emission [32]. Moreover, it is also known that biodiesel contains a lower carbon to hydrogen ration, whose combustion generates a small amount of $\mathrm{CO}_{2}$ emissions $[19,32]$. Similarly, with the increase in load, considering both modes, $\mathrm{CO}_{2}$ shows an increasing trend for all the test fuel blends due to the higher intake air temperature resulting in a complete combustion. The $\mathrm{CO}_{2}$ emission is lowest for the naturally aspirated B50 mode (2.89\%) among all test fuel blends, similarly $\mathrm{B} 20+\mathrm{P}(5.7 \%)$ shows a minimal value for the $\mathrm{CO}_{2}$ emission among all test fuels operated in dual fuel mode at optimum loading conditions.

\section{Hydrocarbon Emission}

Figure 8 elaborates the variation of hydrocarbons with respect to the load. The figure depicts a similar style to that of the $\mathrm{CO}$ emissions. Hydrocarbon emission is higher for 
the dual fuel mode which is around $37.2 \%$ higher than the fossil diesel fuelling mode because of an incomplete combustion at higher loads which might be due to a higher ignition delay of the producer gas that decreases the adiabatic combustion temperature $[19,33]$. Comparing both single and dual fuel modes of operation, the HC emission reduces with an increase in the diesel blend percentage, i.e. B50 stands with the lowest $\mathrm{HC}$ emission. The reason behind the decrement may be due to extra oxygen content in the blends which offers better combustion and spray quality [19, 29]. The HC emission is lowest for B20 (30 ppm) operated in the dual fuel mode in contrast to B20 (10 ppm) operated in the fossil diesel fuelling mode for all test fuels under an optimum loading condition.

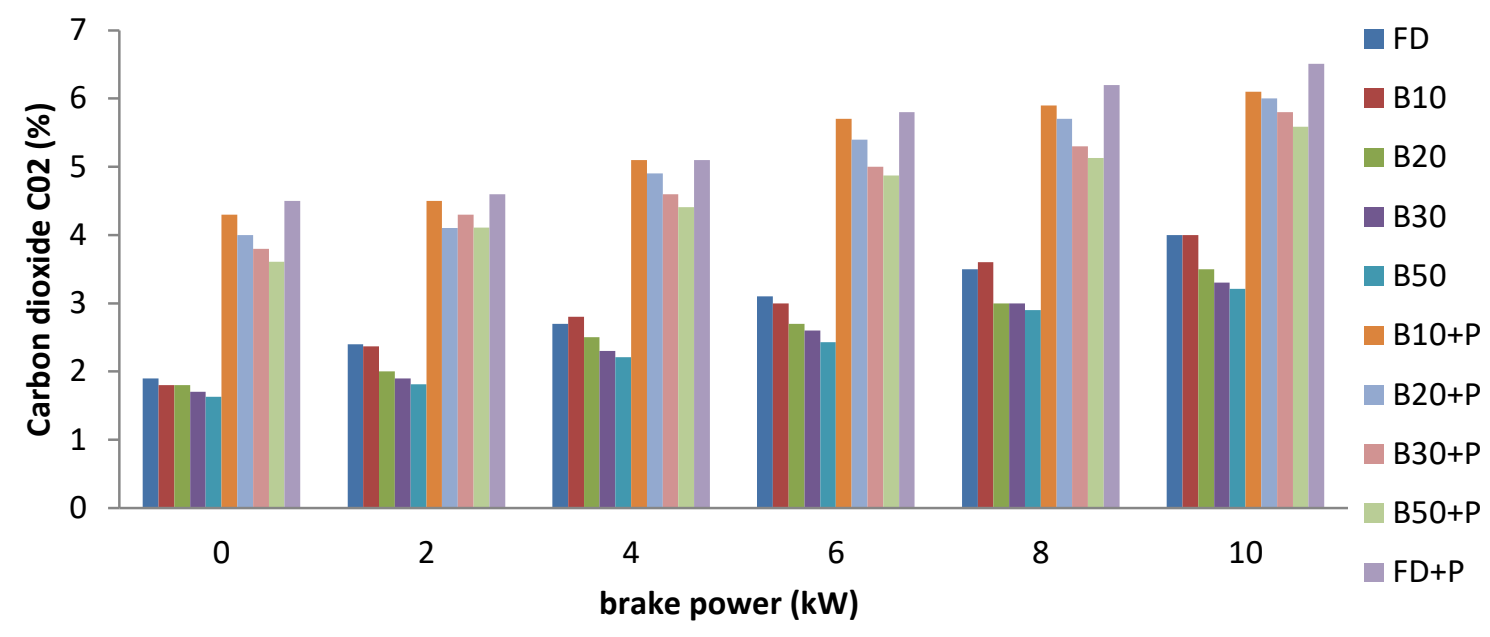

Figure 7. Variation of carbon dioxide with different loads.

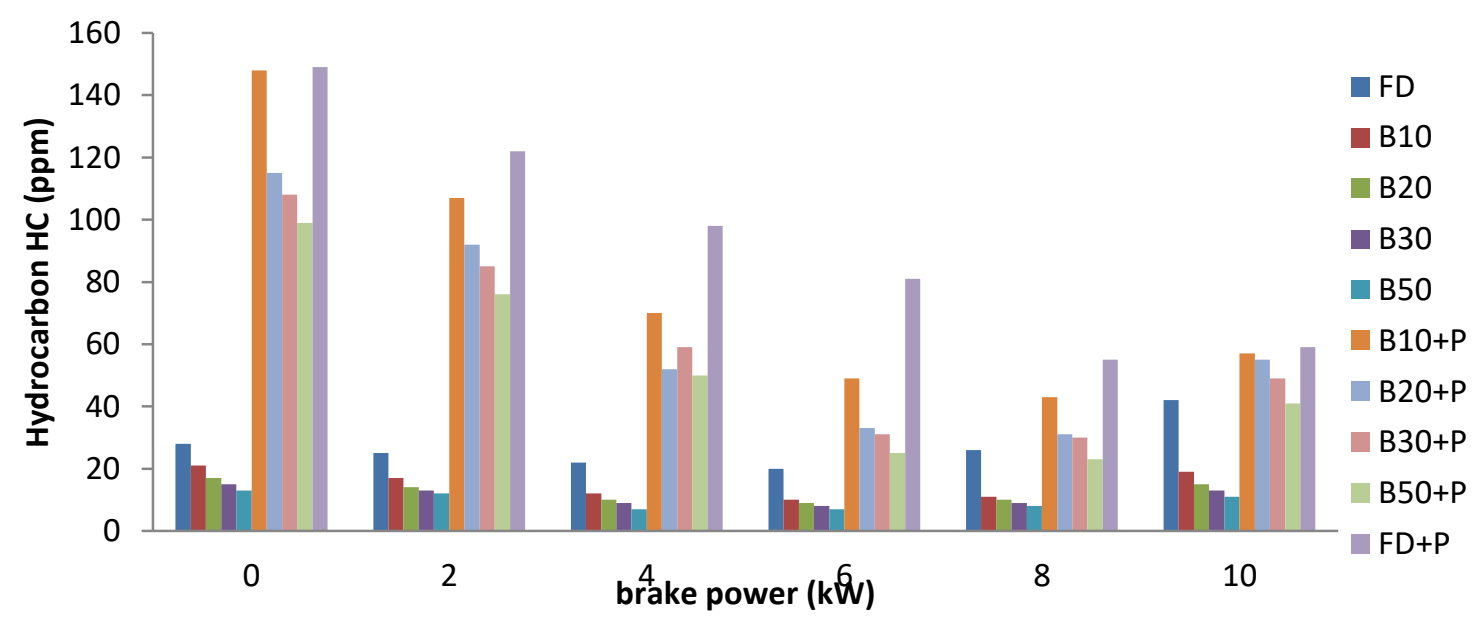

Figure 8. Variation of hydrocarbon with different loads.

\section{Nitrogen Oxide Emission}

The variation of nitrogen oxide with respect to the load is explained in Figure 9. The NOx are produced from the endothermic reaction between nitrogen, oxygen and hydrocarbons especially at a higher temperature during the combustion inside the engine cylinder. NOx gases also react in the atmosphere which may lead to acid rain and smog formation. It can be seen that the NOx emission for the dual fuel mode is very low in comparison to the normal aspirated mode. This may be due to the absence of organic nitrogen in the 
biomass generated producer gas or to the lower adiabatic flame temperature which results in a complete combustion process [32]. An increase in the blend percentage of biodiesel leads to a reduction in the NOx emission for both operating conditions. The reason behind this may be due to low temperature combustion as a result of low energy being released during the pre-mixed phase of combustion because of a bigger droplet size of the test fuel blends [19]. Moreover, it is also observed that with increase in load, the NOx emission increases for all the test fuels in the two modes of operation because of a higher energy input, thereby increasing the combustion temperature for all the prepared test fuel blends $[19,32]$. The figure depicts that the NOx values for fossil diesel, B10, B20, B30 and B50 operated in the dual fuel mode are $(126,119,99,94$ and 80) ppm while those of fossil diesel in the fuelling mode are $(526,423,383,367$ and 345) ppm under an optimum loading condition.

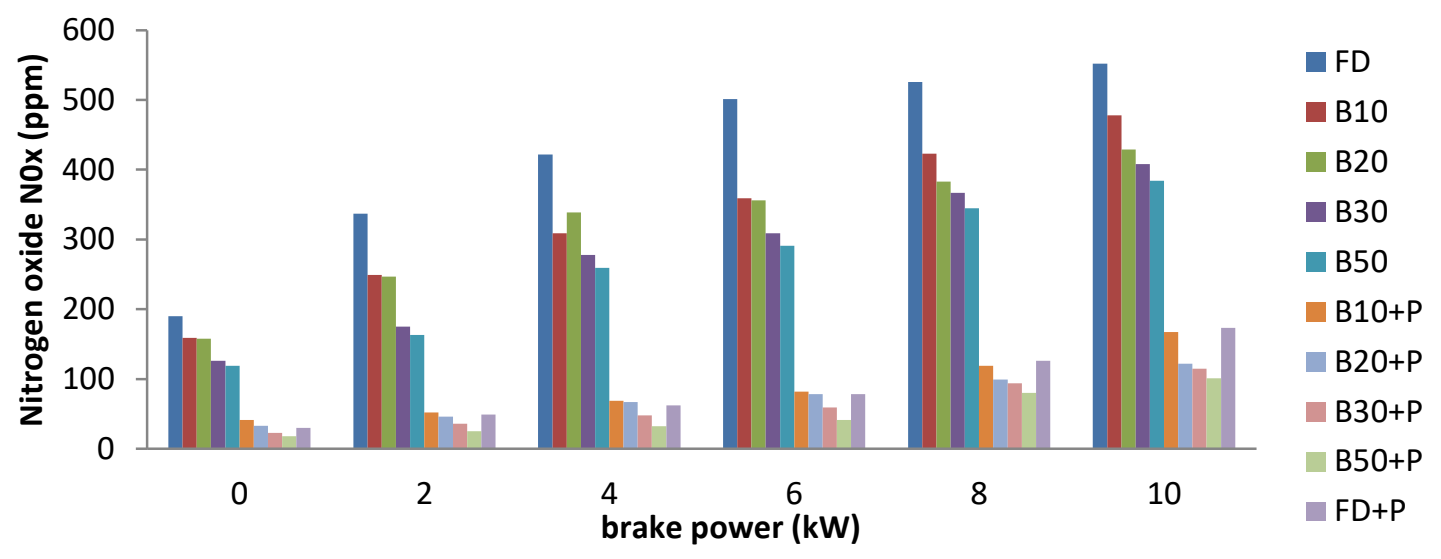

Figure 9. Variation of nitrogen oxide with different loads.

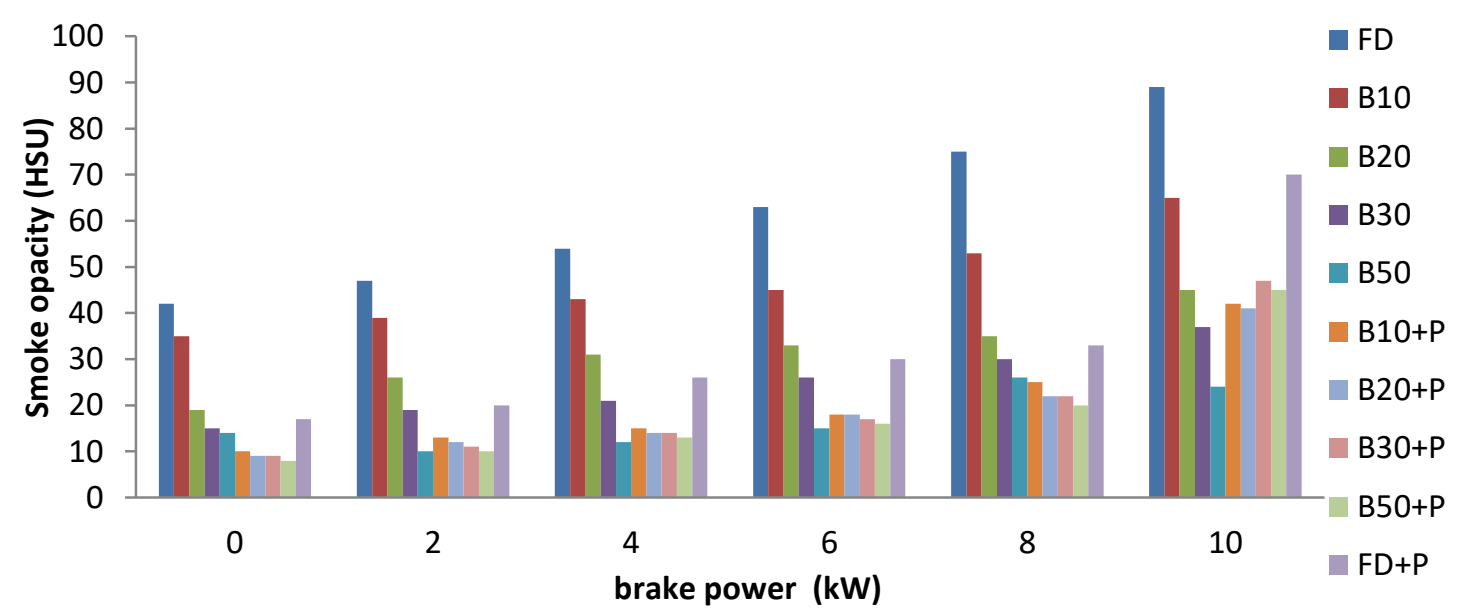

Figure 10. Variation of smoke opacity with different loads.

\section{Smoke Opacity}

Opacity with respect to stacks emission is said to be the degree to which the visibility of a background is reduced by smoke or particulates. Figure 10 reveals the variation of smoke opacity with respect to the load $(\mathrm{kW})$. The above figure indicates that the smoke opacity for dual fuel mode is less in comparison to the naturally aspired mode at optimum loading conditions because of the neat burning of the biomass generated producer gas and 
due to the reduction in the percentage of diesel injection in the dual operating mode [32]. It is also seen that with the increase in the blend percentage, the smoke opacity decreases for all the test fuel blends at optimal loading conditions. This may be a result of the improved combustion on account of excess oxygen content in biodiesel [19, 32]. Furthermore, it can also be observed that with the increase in load, the smoke opacity increases, due to the partial combustion on account of insufficient air in the air-fuel mixture [19]. The smoke opacity for the dual fuel operated mode is lowest for B20 (22 HSU) while in the case of the single fuel mode B20 depicts the value of $35 \mathrm{HSU}$ under an optimum loading condition.

\section{Diesel Fuel Savings}

The variation of diesel fuel savings with respect to the load $(\mathrm{kW})$ for all the prepared test fuel blends is shown in Figure 11. It is quite clear from the figure that diesel fuel savings decrease with the increase in the percentage of biodiesel blends because of a lower calorific value in comparison to that of diesel. The mathematical equation obtained to find out the maximum percentage of diesel savings is

$$
\% \text { Diesel saving }=\frac{\begin{array}{l}
\text { Diesel consumption in natural spirated mode } \\
\text { Diesel consumption in natural aspirated mode }
\end{array}}{\text { Diel consumption in dual fuel mode }}
$$

The above figure depicts the highest diesel fuel savings for fossil diesel (84\%) which is the highest among all test fuels. Similarly, B20 (80\%) shows a fair amount of diesel savings and the result is quite near to that of the fossil diesel under an optimum loading condition.

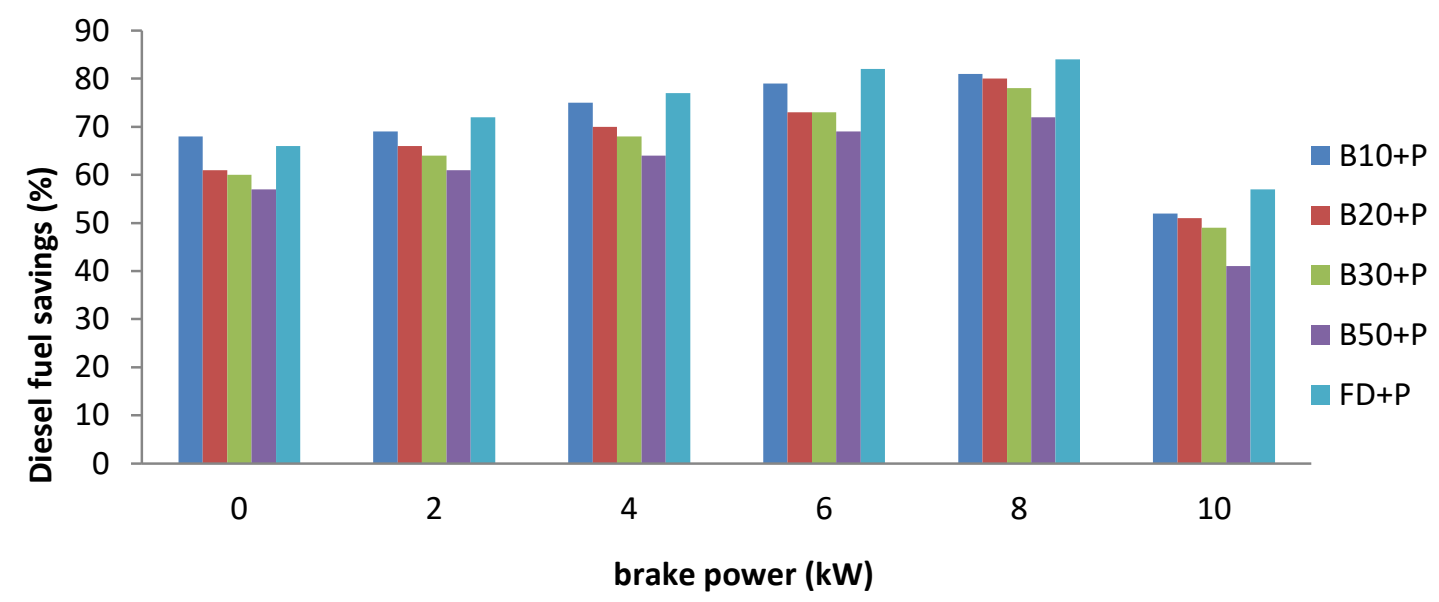

Figure 11. Variation of diesel fuel savings with different loads.

\section{CONCLUSIONS}

This paper focused on the production of producer gas from rice husk and biodiesel from calophylluminophyllum oil in order to determine the emission characteristics of a diesel engine operated in a dual fuel mode, with the aim of eliminating the use of conventional fossil diesel without much engine modification. From the above experimental investigation, it may be concluded that the biomass generated producer gas may be 
utilised as gaseous fuel in the present diesel engine to up to $80 \%$ of the optimum loading condition, beyond which the performance of the engine decreases. Meanwhile, in the literature, it was stated that producer gas can be utilised as potential fuel in a proportion of up to $60 \%$ of the normal loading condition. The following conclusions were drawn from the experimentation:

i) Considering the whole test fuel blends, BSEC and EGT increase, whereas BTE showed a decreasing curve for both modes, which are nearly comparable to that of diesel.

ii) Maximum diesel savings occurred for diesel with producer gas up to $82 \%$, when correlated with the B20 biodiesel blend showing a diesel savings rate of up to $80.6 \%$ at $8 \mathrm{~kW}$ of the optimum loading condition.

iii) Now, taking into account the emission parameters i.e. $\mathrm{CO}, \mathrm{CO}_{2}$ and $\mathrm{HC}$ showed an increasing trend while, the NOx and smoke opacity reduced drastically for the dual operated mode in comparison to the fossil diesel fuelling mode of operation.

Thus, from the above experimental analysis it is confirmed that calophyllum inophyllum biodiesel with biomass generated producer gas at a constant gas flow rate up to $20 \%$ blend i.e. B20 can be utilised as potential fuel for current diesel engines without many engine modifications and problems.

\section{ACKNOWLEDGEMENTS}

The authors are thankful to the School of Mechanical Engineering, KIIT University, for providing experimental setup to complete the experimental work.

\section{REFERENCES}

[1] Nayak SK, Mishra PC. Investigation on jojoba biodiesel and producer gas in dualfuel mode. Energy Sources, Part A: Recovery, Utilization, and Environmental Effects. 2016;38:2265-71.

[2] Adam IK, Aziz ARA, Yusup S. Determination of diesel engine performance fueled biodiesel (rubber seed/palm oil mixture) diesel blend. International Journal of Automotive and Mechanical Engineering. 2015;11:2675.

[3] Mofijur M, Masjuki H, Kalam M, Hazrat M, Liaquat A, Shahabuddin M, et al. Prospects of biodiesel from Jatropha in Malaysia. Renewable and Sustainable Energy Reviews. 2012;16:5007-20.

[4] Dubey P, Gupta R. Study of the performance and emission characteristics for a dual fuel powered single cylinder diesel engine. International Journal of Automotive \& Mechanical Engineering. 2016;13.

[5] Mahgoub BK, Sulaiman S, Karim ZA. Performance study of imitated syngas in a dual-fuel compression ignition diesel engine. International Journal of Automotive and Mechanical Engineering. 2015;11:2282.

[6] (EIA) USEIA. Alternatives to Traditional Transportation Fuels. In: Michele Simmons SOTL, editor. Transportation Fuels. Washington, DC 20585 Office of Coal, Nuclear, Electric and Alternate Fuels U. S. Department of Energy 2008:69.

[7] Vashist D, Ahmad M. Statistical analysis of diesel engine performance for castor and jatropha biodiesel-blended fuel. International Journal of Automotive and Mechanical Engineering. 2014;10:2155. 
[8] Kapilan N, Ashok Babu T, Reddy R. Improvement of performance of dual fuel engine operated at part load. International Journal of Automotive and Mechanical Engineering. 2010;2:200-10.

[9] Nayak SK, Mishra PC. Emission from utilization of producer gas and mixes of jatropha biodiesel. Energy Sources, Part A: Recovery, Utilization, and Environmental Effects. 2016;38:1993-2000.

[10] Nayak SK, Mishra PC. Emission characteristics of diesel fuel composed of linseed oil (Linum Usitatissium) blends utilizing rice husk producer gas. Energy Sources, Part A: Recovery, Utilization, and Environmental Effects. 2016;38:2001-8.

[11] Hasan MM, Rahman MM, Kadirgama K. A review on homogeneous charge compression ignition engine performance using biodiesel-diesel blend as a fuel. International Journal of Automotive and Mechanical Engineering. 2015;11:2199211.

[12] Van der Hoeven M. World energy outlook 2012. Paris: International Energy Agency. 2012.

[13] Khalid A, Jaat N, Sapit A, Razali A, Manshoor B, Zaman I, et al. Performance and emissions characteristics of crude jatropha oil biodiesel blends in a diesel engine. International Journal of Automotive and Mechanical Engineering. 2015;11:2447.

[14] Shukri MR, Rahman M, Ramasamy D, Kadirgama K. Artificial neural network optimization modeling on engine performance of diesel engine using biodiesel fuel. International Journal of Automotive and Mechanical Engineering. 2015;11:2332.

[15] Ghafoori M, Ghobadian B, Najafi G, Layeghi M, Rashidi A, Mamat R. Effect of nano-particles on the performance and emission of a diesel engine using biodieseldiesel blend. International Journal of Automotive and Mechanical Engineering. 2015;12:3097-108.

[16] Azad AK, Rasul MG, Giannangelo B, Islam R. Comparative study of diesel engine performance and emission with soybean and waste oil biodiesel fuels. International Journal of Automotive and Mechanical Engineering. 2015;12:286681.

[17] Adam IK, A. Aziz AR, Yusup S. Determination of Diesel Engine Performance Fueled Biodiesel (Rubber Seed/Palm Oil Mixture) Diesel Blend. International Journal of Automotive and Mechanical Engineering. 2015;11:2675-85.

[18] Hasan M, Rahman M, Kadirgama K. A review on homogeneous charge compression ignition engine performance using biodiesel-diesel blend as a fuel. International Journal of Automotive and Mechanical Engineering. 2015;11:2199.

[19] Ramadhas A, Jayaraj S, Muraleedharan C. Dual fuel mode operation in diesel engines using renewable fuels: Rubber seed oil and coir-pith producer gas. Renewable Energy. 2008;33:2077-83.

[20] Mohd Noor CW, Mamat R, Najafi G, Mat Yasin MH, Ihsan CK, Noor MM. Prediction of marine diesel engine performance by using artificial neural network model. Journal of Mechanical Engineering and Sciences. 2016;10:1917-30.

[21] Kettner M, Dechent S, Hofmann M, Huber E, Arruga H, Mamat R, et al. Investigating the influence of water injection on the emissions of a diesel engine. Journal of Mechanical Engineering and Sciences. 2016;10:1863-81.

[22] Ibrahim F, Wan Mahmood WMF, Abdullah S, Abu Mansor MR. Numerical investigation of soot mass concentration in compression ignition diesel engine. Journal of Mechanical Engineering and Sciences. 2016;10:2275-87. 
[23] Raman P, Ram N. Performance analysis of an internal combustion engine operated on producer gas, in comparison with the performance of the natural gas and diesel engines. Energy. 2013;63:317-33.

[24] Dasappa S, Sridhar H. Performance of a diesel engine in a dual fuel mode using producer gas for electricity power generation. International Journal of Sustainable Energy. 2013;32:153-68.

[25] Nayak SK, Mishra PC. Application of Nagchampa biodiesel and rice husk gas as fuel. Energy Sources, Part A: Recovery, Utilization, and Environmental Effects. 2016;38:2024-30.

[26] Mathur A, Singh U, Vijay Y, Hemlata MS, Sharma M. Analysing performance for generating power with renewable energy source using rice husk as an alternate fuel. IISTE; 2013.

[27] Atabani A, Mahlia T, Badruddin IA, Masjuki H, Chong W, Lee KT. Investigation of physical and chemical properties of potential edible and non-edible feedstocks for biodiesel production, a comparative analysis. Renewable and Sustainable Energy Reviews. 2013;21:749-55.

[28] Atabani A, da Silva César A. Calophyllum inophyllum L.-A prospective nonedible biodiesel feedstock. Study of biodiesel production, properties, fatty acid composition, blending and engine performance. Renewable and Sustainable Energy Reviews. 2014;37:644-55.

[29] Palash S, Masjuki H, Kalam M, Atabani A, Fattah IR, Sanjid A. Biodiesel production, characterization, diesel engine performance, and emission characteristics of methyl esters from Aphanamixis polystachya oil of Bangladesh. Energy Conversion and Management. 2015;91:149-57.

[30] Chauhan BS, Kumar N, Cho HM. A study on the performance and emission of a diesel engine fueled with Jatropha biodiesel oil and its blends. Energy. 2012;37:616-22.

[31] Nayak C, Pattanaik B, Nayak S. Effect of preheated jatropha oil and jatropha oil methyl ester with producer gas on diesel engine performance. International Journal of Automotive and Mechanical Engineering. 2014;9:1709.

[32] Banapurmath N, Yaliwal V, Hosmath R, Tewari P. Life improvement programme of producer gas-biodiesel operated dual fuel engines. International Journal of Sustainable Engineering. 2012;5:350-6.

[33] Agarwal AK, Rajamanoharan K. Experimental investigations of performance and emissions of Karanja oil and its blends in a single cylinder agricultural diesel engine. Applied Energy. 2009;86:106-12.

\section{NOMENCLATURE}

\begin{tabular}{|c|c|c|c|}
\hline $\mathrm{CO}$ & Carbon monoxide & HSU & Heritage smoke unit \\
\hline $\mathrm{HC}$ & Hydrocarbon & $\mathrm{MJ} / \mathrm{m}^{3}$ & Mega joules per cubic meter \\
\hline $\mathrm{kW}$ & Kilowatt & $\mathrm{kg} / \mathrm{m}^{3}$ & Kilogram per cubic meter \\
\hline RPM & Rotation per minute & $\mathrm{KJ} / \mathrm{kg}$ & Kilo joules per kilogram \\
\hline $\mathrm{CO}_{2}$ & Carbon dioxide & $\mathrm{cSt}$ & centi stroke \\
\hline $\mathrm{NO}_{X}$ & Nitrogen oxide & $\mathrm{Nm}^{3} / \mathrm{h}$ & Newton cubic meter per hour \\
\hline EIA & $\begin{array}{l}\text { Energy Information } \\
\text { Administration }\end{array}$ & ppm & Parts per million \\
\hline $\begin{array}{l}\mathrm{HPR} \\
{ }^{0} \mathrm{C}\end{array}$ & $\begin{array}{l}\text { Husk to paddy ratio } \\
\text { degree Celsius }\end{array}$ & $\begin{array}{l}\mathrm{Nm}^{3} \\
\mathrm{~kJ} / \mathrm{Nm}^{3}\end{array}$ & $\begin{array}{l}\text { Newton cubic meter } \\
\text { Kilo Joule per Newton Cubic } \\
\text { meter }\end{array}$ \\
\hline
\end{tabular}




\begin{tabular}{|c|c|c|c|}
\hline $\mathrm{H}_{3} \mathrm{PO}_{4}$ & Phosphoric acid & BTDC & Before top dead center \\
\hline ASTM & $\begin{array}{l}\text { American Society for Testing } \\
\text { and Materials }\end{array}$ & DAS & Data Acquisition System \\
\hline NO & Nitric oxide & B 10 & $10 \%$ biodiesel $+90 \%$ diesel \\
\hline $\mathrm{EN}$ & European norms & $\mathrm{B} 10+\mathrm{P}$ & $\begin{array}{l}10 \% \text { biodiesel }+90 \% \text { diesel }+ \\
\text { producer gas }\end{array}$ \\
\hline FD & Fossil diesel & BSEC & $\begin{array}{l}\text { Brake specific energy } \\
\text { consumption }\end{array}$ \\
\hline EGT & Exhaust gas temperature & BTE & Brake thermal efficiency \\
\hline
\end{tabular}

